\title{
Legacy of a Chemical Factory Site: Contaminated Groundwater Impacts Stream Macroinvertebrates
}

Rasmussen, Jes J.; McKnight, Ursula S.; Sonne, Anne Thobo; Wiberg-Larsen, Peter; Bjerg, Poul Løgstrup

Published in:

Archives of Environmental Contamination and Toxicology

Link to article, DOI:

$10.1007 / \mathrm{s} 00244-015-0211-2$

Publication date:

2016

Document Version

Peer reviewed version

Link back to DTU Orbit

Citation $(A P A)$ :

Rasmussen, J. J., McKnight, U. S., Sonne, A. T., Wiberg-Larsen, P., \& Bjerg, P. L. (2016). Legacy of a Chemical Factory Site: Contaminated Groundwater Impacts Stream Macroinvertebrates. Archives of Environmental Contamination and Toxicology, 70(2), 219-230. https://doi.org/10.1007/s00244-015-0211-2

\section{General rights}

Copyright and moral rights for the publications made accessible in the public portal are retained by the authors and/or other copyright owners and it is a condition of accessing publications that users recognise and abide by the legal requirements associated with these rights.

- Users may download and print one copy of any publication from the public portal for the purpose of private study or research.

- You may not further distribute the material or use it for any profit-making activity or commercial gain

- You may freely distribute the URL identifying the publication in the public portal 
1 Legacy of a chemical factory site: Contaminated groundwater impacts stream macroinvertebrates

3 Jes J. Rasmussen*†, Ursula S. McKnight $¥$, Anne Th. Sonneł, Peter Wiberg-Larsen†, Poul L.

$5+$ Aarhus University, Department of Bioscience, Vejlsoevej 25, 8600 Silkeborg, Denmark

$6 \mp$ Technical University of Denmark, Department of Environmental Engineering, Miljoevej Build.

$7 \quad 113,2800$ Kgs. Lyngby, Denmark

8

9 * Corresponding author:

10 Jes Jessen Rasmussen

11 e-mail: jr@bios.au.dk

12 Office phone: $(+45) 87158779$

13 
Legislative and managing entities of EU member states face a comprehensive task since the chemical and ecological impacts of contaminated sites on surface waters need to be assessed. The

31 Key words: Groundwater contaminants, contaminated sites, macroinvertebrates, morphological ecological assessment is further complicated by the low availability, or in some cases, absence of ecotoxicity data for many of the compounds occurring at contaminated sites. We studied the potential impact of a contaminated site, characterised by chlorinated solvents, sulfonamides and barbiturates, on benthic macroinvertebrates in a receiving stream. Most of these compounds are characterised by low or unknown ecotoxicity, but they are continuously discharged into the stream via a long-lasting source generating a long-term chronic exposure of the stream biota. Our results show that taxonomical density and diversity of especially sediment dwelling taxa were reduced by $>50 \%$ at the sampling sites situated in the primary inflow zone of the contaminated groundwater. Moreover, macroinvertebrate communities at these sampling sites could be distinguished from upstream control sites and sites situated along a downstream dilution gradient using multidimensional scaling. Importantly, macroinvertebrate indices currently used did not identify this impairment, underpinning an urgent need for developing suitable tools for the assessment of ecological effects of contaminated sites in streams.

$$
\text { deformities, Chironomidae, Chlorinated solvents }
$$




\section{INTRODUCTION}

Historical depositions of environmental contaminants on e.g. industrial sites and landfills may be transported to surface water via groundwater. The transport of xenobiotic organic compounds from these types of contaminated sites to surface waters will differ in space and time depending on the amount of deposited compounds and the connectivity of the sites with groundwater (Conant et al. 2004; Milosevic et al. 2012; Westbrook et al. 2005). According to the EU Water Framework Directive (Directive 2008/105/EC), member states are obliged to assess the risk of all contaminated sites that may impact chemical and ecological quality of streams and lakes via groundwater transport. Ideally, the ecological impairment in streams caused by contaminated sites should be disentangled from the effects of other stressors, such as diffuse source pollution from agricultural and urban settings, in order to evaluate their importance (McKnight et al. 2012; Rasmussen et al. 2013; Roy and Bickerton 2012; Tesoriero et al. 2013).

Contaminated sites near surface water bodies may harbour a substantial array of compounds, including e.g. chlorinated solvents, gasoline constituents, pharmaceutical compounds, metals and metalloids, and pesticides (Chapman et al. 2007; Dickman and Rygiel 1998; McKnight et al. 2010; Milosevic et al. 2012; Westbrook et al. 2005). Only a fraction of these contaminants are routinely monitored in streams (especially pesticides and metals) while other compounds may be overlooked because they fail to meet the central criteria for ecological concern (toxicity, persistence and bioaccumulation). Importantly, contaminants with low predicted ecotoxicity to aquatic biota may still be harmful when the contaminants are continuously discharged into surface waters via longlived sources (e.g. on the order of tens to hundreds of years) resulting in year-long chronic exposure scenarios (Conant et al. 2004; Daughton 2005; Weatherill et al. 2014). 
The ecological impacts of contaminated sites on macroinvertebrates have been documented in a few studies where e.g. stream water samples were collected in the proximity of a contaminated groundwater inflow zone and subsequently used for standard laboratory toxicity tests (Plotkin and Ram 1984), or where benthic samples representing a dilution-mediated pollution gradient, i.e. collected within the groundwater inflow zone and up to few hundred meters downstream, were assessed (Dickman and Rygiel 1998). However, studies are still needed that investigate the structural changes of especially sediment dwelling invertebrate communities along streams that are intersected with contaminated groundwater inflow. Specifically, insight on the spatial extent of the ecological effects of contaminated sites downstream of the primary contaminated groundwater inflow zones is needed.

Benthic stream macroinvertebrates have traditionally been used as indicators for various anthropogenic stressors since their sensitivity to these is high and their life span sufficiently long to integrate effects (Rosenberg and Resh 1993). In European countries, the ecological quality assessment is typically based on indices/metrics reflecting the effect of oxygen depletion due to the degradation of non-toxic organic substances. One example is the ASPT (Average Score Per Taxon) developed in the U.K. (Armitage et al. 1983) and modified for use in several other European countries. The Danish Stream Fauna Index (DSFI) (Skriver et al. 2000) also belongs in this category. Unfortunately, indices of this type generally have a low capability to capture the effects of toxicants (Beketov and Liess 2008; Liess and von der Ohe 2005; McKnight et al. 2012). One plausible explanation for this is that they are based on indicator species for high oxygen concentrations, which is not necessarily linked to a high sensitivity for toxicants (Rubach et al. 2010). Consequently, alternative indices targeting e.g. organic toxicants (Beketov and Liess 2008) 
6

and diffuse source pesticide pollution (Liess and von der Ohe 2005) have been developed to better characterise the ecological effects of toxicants.

However, compound-specific standard toxicity data is not necessarily existing or available to an extent that allows these types of ecological risk assessments of freshwater systems to be carried out. Moreover, even when such data exists, current risk assessments based on laboratory and mesocosm data tend to underestimate the ecological effects of e.g. pesticides observed in the field (Beketov et al. 2013; Schäfer et al. 2012). There are indications that other chemicals, in spite of their predicted low ecotoxicity such as chlorinated solvents, may also exacerbate the viability of stream macroinvertebrate communities. For example, a recent study by Houde et al. (2015) revealed effects of trichloroethylene (TCE) and vinyl chloride (VC) on genes and proteins related to metabolism, reproduction and growth in D. magna at environmentally relevant concentrations (i.e. $\mu \mathrm{g} \mathrm{L}^{-1}$ ). In consequence, using standard toxicity test data to predict field-effects of the continuous exposure of chemicals with low predicted ecotoxicity will lead to inadequate quantification of the ecological impacts that are only visible after successive generations of stream biota (sensu Liess and von der Ohe (2005)).

(1)

The sediment dwelling macroinvertebrates, often dominated by species of Chironomidae (Diptera), are potentially highly relevant stream indicators for contaminated groundwater inflow since they reside in the contact zone between groundwater and surface water (Dickman and Rygiel 1998). The taxon density of Chironomidae, however, does not necessarily reflect pollution gradients (Dickman and Rygiel 1998; Lenat 1983), and species of especially Chironomidae differ widely in their habitat preferences with respect to flow regimes, stream size and bed substrate composition (Lenat 1983; Milosevic et al. 2013). Moreover, the duration of chironomid life-cycles varies strongly among 
taxa, translating into a strong temporal variation in chironomid community structure. This complicates the use of the taxonomic community composition of Chironomidae as a general pollution indicator tool (Milosevic et al. 2013). Nevertheless, quantifying the community sensitivity of all sediment dwelling macroinvertebrates to organic contaminants (sensu Beketov and Liess (2008)) may provide a tighter link to the continuous exposure of contaminated groundwater inflow.

\section{Morphological deformities of sediment dwelling Chironomidae larvae have additionally been} suggested as useful indicators for toxicant exposure to e.g. chlorinated compounds (Meregalli et al. 2001; Watts et al. 2001; Watts et al. 2003), pesticides (Gagliardi and Pettigrove 2013), metals (Di Veroli et al. 2012; Dickman and Rygiel 1996), and as an effect screening tool for unknown pollutants (Lenat 1993). The coupling between morphological deformities of Chironomidae and ecologically relevant parameters (e.g. life cycle endpoints, reproductive output and population dynamics) has not, however, been fully clarified. The use of Chironomus spp. as an indicator for various pressures of chemical pollution may be partly constrained by naturally occurring high background ratios of deformities, complicating the documentation of clear concentration-response effects (Lenat 1993). Species of the genus Prodiamesa have lower background rates of morphological deformities but may still respond to toxicant exposure (Servia et al. 1998). Thus, Prodiamesa spp. may be a useful supplement to Chironomus spp. as a bioindicator for toxicant stress.

We studied a $16 \mathrm{~km}$ reach of Grindsted stream (Denmark), where the stream flow is dominated by groundwater inflow. Contaminated groundwater originating primarily from an old factory site in Grindsted town discharges into the central part of the studied stream reach. Major contaminants include chlorinated solvents and their metabolites, and pharmaceutical products. We sampled 
macroinvertebrates at 7 sampling sites along the stream continuum representing an upstream control, contaminated groundwater discharge zones and a downstream dilution gradient. The overall aim of the study was to characterise macroinvertebrate communities at the sampling sites and evaluate the ability of currently used ecological indicator tools for characterising the contaminant effects. In addition, we aimed to characterise the spatial extent of the potential effect of a local groundwater-mediated contamination of the stream. We hypothesized that i) the contaminated groundwater would primarily affect macroinvertebrates in the contaminated groundwater discharge zones and not downstream sampling sites with elevated stream water concentrations and no contaminated groundwater inflow, ii) sediment dwelling macroinvertebrates respond more strongly to contaminated groundwater inflow compared to an analysis of the entire macroinvertebrate community, iii) the frequency of morphological deformities in Chironomus spp. and Prodiamesa spp. increases in the contaminated groundwater discharge zone, and iv) the SPEARorganics index, targeting the effects of organic contaminants, provides a superior prediction of ecological effects of the investigated contaminants compared to currently used biotic indices (e.g. ASPT and DSFI).

\section{MATERIAL AND METHODS}

\section{Contaminated site at Grindsted and catchment characteristics}

The Grindsted factory site is located approximately $1.5 \mathrm{~km}$ from Grindsted stream (Fig. 1). The Grindsted factory has produced various chemicals since 1914, including explosive material, pharmaceutical compounds and enzymes (NIRAS 2009). More than 1,000 chemicals have been handled at Grindsted factory during the last century, and large quantities of chemicals were deposited within the factory site up to the mid-1990s. At present, the factory is not active and the deposition of hazardous chemicals on the factory site has stopped. The contaminated site is characterised by environmental toxicants including chlorinated solvents and their metabolites, as 
well as pharmaceutical compounds such as barbiturates and sulphonamides (NIRAS, 2009), and many of these contaminants are transported to Grindsted stream via groundwater (Nielsen et al. 2014).

The catchment of Grindsted stream is approximately $200 \mathrm{~km}^{2}$ and is dominated by sand and sandy clay (Heron et al. 1998). Agriculture and urban settings comprise approximately $54 \%$ and $12 \%$ of the total catchment, respectively. The annual rainfall is $750-850 \mathrm{~mm}$. The stream flow ranged from $1152 \mathrm{~L} / \mathrm{s}^{-1}$ to $2249 \mathrm{Ls}^{-1}$ from the up-gradient station S7 to the down-gradient station S1. The studied stream reach receives only a small amount of surface water input via stream tributaries.

\section{Discharge zone identification, contaminant sampling and analyses}

The water temperature was systematically monitored along $50 \mathrm{~m}$ intervals at $50 \%$ and $100 \%$ of the water depth, and $20 \mathrm{~cm}$ below the streambed $\left(\mathrm{T}_{20}\right)$ (Fig. S1a-b). The stream water temperature was $13-14{ }^{\circ} \mathrm{C}$, and groundwater temperature $8-10{ }^{\circ} \mathrm{C}$ in August/September 2012. $\mathrm{T}_{20}<10^{\circ} \mathrm{C}$ was thus interpreted as a potential groundwater discharge zone, and confirmed by hydraulic head measurements (Nielsen et al. 2014). Samples were extracted from the hyporheic zone (HZ) using piezometers placed $40 \mathrm{~cm}$ below the streambed along the investigated stretch of Grindsted stream (Fig. S1c). Moreover, stream water (SW) samples were manually collected in the middle of the water column every 50-100 m (Fig. S2). HZ and SW samples were analysed for 9 chlorinated solvents and 44 pharmaceutical compounds (barbiturates and sulfonamides; Table S1).

In total, $48 \mathrm{SW}$ and $38 \mathrm{HZ}$ samples were analysed for chlorinated solvents (Table 1). A subset of these samples, based on the results from the chlorinated solvents, were then further analysed for barbiturates and sulfonamides, specifically $5 \mathrm{SW}$ and $2 \mathrm{HZ}$ samples (Table S1). Samples for 
chlorinated solvents were collected in $40 \mathrm{~mL}$ glass vials, preserved with $4 \mathrm{M} \mathrm{H}_{2} \mathrm{SO}_{4}$ and stored at 4 ${ }^{\circ} \mathrm{C}$. The analytes were extracted using the "head-space" method, and subsequently separated and identified on a GC-MS (Agilent 7980 gas chromatograph equipped with an Agilent 5975 Celectron impact $(70 \mathrm{eV})$ triple-axis mass-selective detector). Limits of detection and quantification were determined following the methods provided in Winslow et al. (2006) (Table S1). We additionally included SW data extracted from Petersen (2012) in order to improve the interpretive power when linking toxicant concentrations to macroinvertebrate data (Table S2).

\section{Sampling sites}

We investigated seven sampling sites in this field study representing $15,800 \mathrm{~m}$ of Grindsted stream (Fig. 1). The spatial allocation of sites was based on measured contaminant concentrations in stream water sampled in autumn 2011 (Petersen 2012). We chose sampling sites near and downstream of the discharge zone where contaminated groundwater (GW) from the Grindsted factory site was found to enter SW. One additional site approximately 7,000 m upstream of the contaminated GW discharge zone was included as a control (S7). One site was positioned just upstream of the contaminated GW discharge zone (S6), two sites were positioned in the contaminated GW discharge zone (S4 and S5), and the three final sites represented a dilution gradient along the stream course downstream of the contaminated GW discharge zone (S1-S3) (Fig. 1). Each sampling site refers to a $50 \mathrm{~m}$ reach used for macroinvertebrate sampling, physical characterisation and water sampling for general water chemistry.

\section{Physical stream parameters}

At each sampling site the relative coverage of stones/boulders, gravel, sand and mud was estimated along each of ten transects. These transects were evenly spaced by $5 \mathrm{~m}$ along the $50 \mathrm{~m}$ reach. 
Moreover, we quantified the relative coverage of undercut banks ( $\%$ of reach length), roots ( $\%$ of reach length), high energy flow types (\% of the $50 \mathrm{~m}$ reach), and emergent and submergent vegetation (\% of the $50 \mathrm{~m}$ reach).

\section{General water chemistry}

Three $1 \mathrm{~L}$ water samples were collected manually at each of the seven sampling sites in September 2012 for analyses of general water chemistry. We measured biological oxygen demand $\left(\mathrm{BOD}_{5}\right)$, ammonia-N, nitrate-N, total-N (unfiltered samples), ortho-phosphate, total-P (unfiltered samples), suspended solids and the organic fraction of suspended solids. The $\mathrm{BOD}_{5}$, ortho-phosphate and ammonia-N were analysed following their European Standards (DS/EN 1899 1999, DS/EN 11891997 and DS 11732 2005, respectively). Nitrate-N was analysed by applying the Lachat-method (Lachat Instruments, USA, Quickchem. No. 10-107-06-33-A (Salycate method)). Total-N and totalP were measured using the Kjeldahl-N method and Danish standard DS-291, respectively. Suspended solids were measured filtering water through a Whatman GFC filter (pore size $1.2 \mu \mathrm{m}$ ) and subsequently drying the filter at $105^{\circ} \mathrm{C}$ for $24 \mathrm{~h}$. The organic fraction of the suspended solids was measured as the weight loss of the suspended solids after heating at $550{ }^{\circ} \mathrm{C}$ for $24 \mathrm{~h}$. Water temperature, conductivity and oxygen concentration were registered at each site using a multi-meter (WTW multi-350i) and pH was measured with a (YSI-60) pH-meter.

\section{Macroinvertebrate sampling and identification}

Macroinvertebrates were collected from all 7 sampling sites in September 2012 using a $500 \mathrm{~cm}^{2}$ surber sampler attached to a shaft. At each sampling site, 12 surber samples were collected and pooled into one composite sample in the field, and were preserved using $96 \%$ ethanol. The surber samples were collected along three transects at 0,25 and $50 \mathrm{~m}$ of the reach used for physical 
characterisation. Along each transect, four surber samples were collected at 25, 50, 75 and 100\% of the distance from the left bank to the right bank.

All invertebrates were counted and identified to the level of species or genus (Table S2).

Chironomidae larvae were identified using the keys of Wiederholm (1983), Vallenduuk \& Moller

Pillot (2007) and Moller Pillot (2009). Simuliidae larvae were identified using the key of Jensen

Wallace et al. (2003), and the remaining macroinvertebrates were identified using the keys provided in Nilsson (2005).

\section{Mouthpart deformities of Chironomidae}

Mouthpart deformities in Chironomus spp. were not quantifiable because only four individuals

belonging to this genus were found, and they only represented the upstream control (S7) (Table S4).

We identified morphological deformities in Prodiamesa olivacea and focused on mentum and antennae deformities (Al-Shami et al. 2010; Lenat 1993). Assessment of the severity of deformities (slight, conspicuous, obvious) was performed according to Lenat (1993) and Servia et al. (1998).

\section{Data treatment}

Based on the macroinvertebrate data for each of the 7 sampling sites, we calculated the taxonomic assessed following Skriver et al. (2000), the ASPT was assessed following Armitage et al. (1983) and the SPEARorganics and SPEARpesticides index values were computed using the online and freely available Species At Risk calculator (http://www.systemecology.eu/spear/spear-calculator/). 
The SPEARorganics index is based on the sensitivities of macroinvertebrate taxa to synthetic organic toxicants such as pesticides, surfactants and petrochemicals, and the index value represents the general community tolerance to synthetic toxicants based on existing standardised toxicity tests (Beketov and Liess 2008). Hence, we applied this measure to detect macroinvertebrate community effects of the contaminants originating from the factory site. The SPEARpesticides index aims to detect community changes due to periodic pesticide pollution typically occurring in agricultural streams (Liess and von der Ohe 2005), and we applied this measure to evaluate the potential, but not quantified, influence of diffuse source pesticide pollution from conventional agriculture.

The taxonomic density, total abundance, Simpson index, Shannon index and Brillouin's index were computed for all sampled taxa, for sediment dwelling taxa and for Chironomidae, respectively. Since ASPT and DSFI are not specifically developed for sediment dwelling taxa, we did not compute these indices for this group of taxa. We calculated the SPEARpesticides values for all taxa, since we used this index to evaluate general effects of diffuse source pesticide pollution. Lastly, we did not calculate the SPEARorganics based on Chironomidae, since the data resolution behind the SPEARorganics is currently insufficient to allow for a proper separation of the species of this family (Beketov and Liess 2008).

The taxonomic macroinvertebrate community composition for each sampling site was furthermore analysed using Nonmetric Multidimensional Scaling (NMDS) in PRIMER (Clarke and Warwick 2001). We scaled Bray-Curtis similarities based on $4^{\text {th }}$ root transformations of species abundance data to down weight dominant taxa, and ordinated using 100 runs. Analyses were performed considering all taxonomic groups, as well as the isolated group of sediment dwelling organisms. 


\section{RESULTS AND DISCUSSION}

\section{Contaminant concentrations}

The concentrations of chlorinated compounds within the region S3-S5 (Fig. 1) showed that sampling site S4 was characterised by the highest contaminant concentrations in GW, confirming that this area was an important discharge zone for the contaminated GW entering SW from the factory site (Table 1). Specifically, the contaminant concentrations in the $\mathrm{HZ}$ at site $\mathrm{S} 4$ were a factor of 2-50 higher than the concentrations found in the SW. In general, the concentrations of chlorinated compounds in SW at site S5 were higher than those from the HZ at S5. Moreover, the concentrations of chlorinated compounds in SW at site S5 were higher compared to those found in SW at site S6. This indicates that contaminated GW additionally enters Grindsted stream between sites S5 and S6. No contaminants associated with the contaminated factory site were detected in SW at the upstream sites S6 and S7 in 2011 and 2012 (Tables 1, S2 and S3). Importantly, patterns similar to those identified for the chlorinated solvents were found for concentrations of both the sulfonamides and barbiturates (Tables 1, S2 and S3).

The concentrations of chlorinated compounds were found to continuously decrease in SW downstream of site S4. Notably, VC was still detected at concentrations 4-20 times above the Danish environmental quality standard (EQS) for surface water $\left(0.05 \mu \mathrm{g} \mathrm{L} \mathrm{L}^{-1}\right.$, see Table $\left.\mathrm{S} 1\right)$ at site $\mathrm{S} 2$ (5,000 m downstream of S4). The concentration of VC in the HZ at S4 exceeded the Danish groundwater quality criterion $\left(0.2 \mu \mathrm{g} \mathrm{L}^{-1}\right)$ by up to a factor of 1,000 (Table 1$)$. The decreasing concentrations of chlorinated compounds downstream of the site S4 probably reflect a combination of volatilization (Aisopou et al. 2015) and dilution due to significant inflow of less contaminated GW (see Table 3). The overall stream discharge increased approximately $100 \%$ from the upstream location S7 to the downstream site S1. 
297 Finally, it should be noted that the distribution of GW discharge zones and the contaminant 298 concentrations in the GW discharge into Grindsted stream may vary (Nielsen et al. 2012) and in 299 general, the spatial-temporal variation of groundwater can be relatively large (Anibas et al. 2011;). 300 Hence, especially the HZ samples may not always represent the highest hyporheic zone 301 concentrations in the sampling area.

\section{Physical properties and general water chemistry}

Physical parameters and general water chemistry are known to strongly influence macroinvertebrate taxon density and community structure, but the sampling sites were highly comparable with respect to the physical and chemical site properties (Tables 3 and 4). The substrate composition of the sampling sites generally reflected the strong dominance of sandy soil types in the catchment with sandy substrate dominating at all sites (Table 3). Whereas the relative coverage of sandy substrate complexity with considerable sediment fractions of gravel and mud, which may govern increased macroinvertebrate taxonomic density (Kovalenko et al. 2012). Furthermore, submerged and emergent vegetation covered $66 \%$ to $90 \%$ of the sampled reaches, which is typical for Danish lowland streams (Baattrup-Pedersen and Riis 1999). Generally, the macrophyte community composition is an important parameter governing macroinvertebrate taxon density (Ferreiro et al. 2014; Whatley et al. 2014). Although not quantified in this study, we observed that Berula erecta and Sparganium sp. dominated the vegetation at all sites. Hence, we do not expect significant differences in macrophyte community composition among sites. Finally, the general water chemistry was also found to be highly comparable among sites (Table 4), and the measured concentrations of macro-nutrients and $\mathrm{BOD}_{5}$ are not expected to significantly influence the 
macroinvertebrate community (Friberg et al. 2010). In summary, this indicates that contaminated groundwater inflow, dominated by VC, cis-DCE and sulfonamides, were the most important factors separating the sampling sites with respect to physical and chemical properties.

\section{Macroinvertebrate community responses}

The sites S4 and S5 were characterised by reduced taxa density, but only S4 was additionally characterised by reduced diversity scores (Table 2) compared to both upstream as well as downstream sites. Moreover, the EPT taxa density was reduced to four taxa at S4 compared to upstream and downstream sites (5-10 taxa). These results probably reflect that site S4 contained the highest concentrations of chlorinated and pharmaceutical compounds in both SW and the HZ (Table 1) suggesting that contaminated groundwater inflow is likely an important factor governing the observed ecological impairment at site S4. In theory however, the taxonomic density should only be compared if species accumulation curves for the samples have reached asymptotic equilibrium and if a similar number of organisms have been collected (Gotelli and Colwell, 2001). Importantly, site S4 was characterised by the highest total macroinvertebrate abundance $(>5,000)$ compared to all other sites (Table 2). This means that more organisms should have been collected at all other sites in order to optimize the comparison of taxa density among sites, and this would likely have resulted in an increase in taxa densities at these other sites. Hence, our results likely underestimate the impact of the contaminated GW inflow on the total taxonomic density at site S4.

The NMDS analysis resulted in a strong two-dimensional ordination of the macroinvertebrate communities (level of stress $=0.01)($ Fig. 2). The sites S4 and S5, characterised by lower taxa density and in part lower diversity (Table 2), were ordinated in close proximity to each other. There was a tendency that sampling sites with increasing physical distance to S7 were ordinated with 
increasing distance to S7 (Fig. 2). This could reflect that the contaminated GW discharging into Grindsted stream around sites S4 and S5 may influence macroinvertebrate communities up to 8,000 meters downstream (site S1). However, various diffuse source urban pollutants (not covered in our list of analytes), generally characterising urban settings (Roy and Bickerton 2012), may influence macroinvertebrate communities downstream of Grindsted city and hence be important coexplanatory factors for the observed deviation of downstream sites (Fig. 2).

\section{Sediment taxa}

The sediment dwelling taxa at sites S4 and S5 were characterised by lower taxonomical density and diversity compared to upstream and downstream sampling sites (Table 2), thereby showing a slightly more clear impairment compared to the macroinvertebrate community descriptors based on all taxonomical groups. In contrast to the NMDS analysis of all taxonomical groups (Fig. 2), this was additionally supported by the NMDS analysis of sediment dwelling taxa (level of stress $<0.01$, showing a very strong two-dimensional ordination) where sites S4 and S5 were clearly separated from both up- and downstream sites (Fig. 3). These results suggest that the community composition of sediment dwelling taxa may provide a stronger link to the contaminated GW inflow compared to the full fauna samples. Intuitively, this is reasonable as sediment dwelling organisms reside deeper in the groundwater-surface water interaction zone and are thus exposed to higher contaminant concentrations than swimming and crawling taxa (Tables 1, S2 and S3).

The abundance of sediment dwelling organisms was approximately 10-fold higher at control site S7 compared to sites S1-S6 (Table 2), which is likely explained by a higher habitat complexity and in particular, higher fractions of fine particulate organic material and mud (Table 3). Moreover, higher fractions of mud at S7 could indicate higher sediment stability which, additionally, has a positive 
influence. Sediment instability is an important constraining factor that should be carefully considered in studies addressing the effects of GW contaminants on sediment dwelling macroinvertebrates (Lenat et al. 1981).

In spite of the relatively clear differentiation of sediment dwelling macroinvertebrates at sites S4 and S5 (Fig. 3), generally few individuals of these taxa were found in all samples (Table 2), except at site S7. The site S7 was characterised by higher fractions of fine particulate organic matter and mud possibly indicating higher sediment stability, which has a positive influence on the abundance of sediment dwelling organisms (Lenat et al. 1981). Moreover, inorganic sediments, dominating at sites S1-S6, generally contain fewer taxa and lower abundances of sediment dwelling organisms such as Chironomidae compared to sediments containing higher amounts of organic material (Brunke and Gonser 1999). In consequence, the stringent focus on sediment dwelling macroinvertebrates as bioindicators for contaminated GW in future monitoring and research efforts could be confounded at sites with naturally high sediment instability and low content of particulate organic carbon. We therefore suggest that future studies should additionally focus on meio-fauna communities residing in the deeper and more stable parts of the sediments, as suggested by Brunke and Gonser (1999). Importantly, meio-fauna community composition has been shown to change along concentration gradients of other toxicants such as metals (Höss et al. 2011). Since inflowing GW facilitates the clearing of finer sediment particles in groundwater-surface water interaction zones, future studies should focus especially on sediment dwelling macroinvertebrates and meiofauna connected to habitats with low organic carbon content.

\section{Morphological deformities in Chironomidae larvae}


Mouthpart deformities were studied only in Prodiamesa olivacea, since only four individuals of the Chironomus spp. were detected in the fauna samples, and then only in the sample collected at S7. In total, 24 specimens of $P$. olivacea were found of which only 3 had visible deformities of the mentum ranked as classes I or II according to Servia et al. (1998). The morphological deformities were associated with individuals from sites S5 and S6 (Table 2). Since the background deformity rate of $P$. olivacea is low $(\sim 2 \%)$, these results insinuate effects of anthropogenic stress (Servia et al. 1998), but no contaminants from the factory site were detected at the site S6 precluding a clear cause-effect relationship between the measured contaminant concentrations and mouthpart deformity rates. However, since only two individuals of P. olivacea were found at sites S3-S5 (characterised by contaminated GW inflow), we cannot draw firm conclusions on the sensitivity of morphological deformities of $P$. olivacea to the contaminated GW in this study. Other studies have documented increased deformity rates in another species of Chironomida (Chironomus riparius) exposed to organic contaminants (Meregalli et al. 2001; Watts et al. 2001; Watts et al. 2003). Morphological deformities of Chironomidae have the potential to become a useful indicator of ecological effects caused by GW contaminants, but obviously the use of such an effect indicator is constrained to surface water bodies that naturally harbour higher abundances of the required species. This important restriction could therefore disqualify the use and implementation of morphological deformities of Chironomidae as general bioindicators for documenting the effects of contaminated GW in monitoring programs.

\section{Macroinvertebrate indices}

All macroinvertebrate samples obtained a DSFI score of 5 indicative of "good ecological quality" (Table 2). The number of positive diversity groups was highest at the upstream control site S7 and lowest at site S4, but there was no clear link between the number of positive diversity groups and 
measured contaminant concentrations. Thus the DSFI index, currently the only macroinvertebratebased index in use for assessing ecological quality in Denmark, did not reflect the observed macroinvertebrate community changes at especially sites S4 and S5 (lower taxonomical density and separation of the sites using multi-dimensional scaling (Figs. 2 and 3)). Similarly, the ASPT index did not respond to the detected GW contaminants (Table 2). Similar findings were obtained by McKnight et al. (2012) who studied the effects of a TCE and cis-DCE plume on the ecological status of a stream. Consequently, alternative ecological indicator tools are needed for the characterisation of ecological impacts of contaminated sites.

The SPEARorganics scores were comparable across sites S3-S6, and slightly higher compared to sites S1-S2 and S7 (Table 2). Notably, higher scores are indicative of lower impact of organic toxicants, but the scores for all seven sites remain within the expected range of reference sites $(\geq-$ 0.4) as reported by Beketov and Liess (2008). The SPEARorganics index is based on $\mathrm{LC}_{50}$ values for freshwater macroinvertebrates exposed for $24 \mathrm{~h}$ or $48 \mathrm{~h}$ (data provided in von der Ohe and Liess 2004). Acute mortality data for Daphnia magna (Table S1) exists only for a few of the dominant compounds detected in SW and the HZ in Grindsted stream (TCE, cis-DCE, VC and sulfonamides), but they consistently have $\mathrm{LC}_{50}$ concentrations $>1 \mathrm{mg} \mathrm{L}^{-1}$, thus being a factor 10 to 1,000 above the measured concentrations in the HZ. The findings of Baun et al. (1999; 2000) further support the prediction that the GW contaminants are not acutely lethal to D. magna. Comparing the SPEARorganics results with the reduced taxonomic densities observed at sites S4 and S5 in especially sediment dwelling species, this could imply that the predicted taxonomic sensitivities are based on insufficient data to correctly identify sensitive populations. Equally important, the substantial scarcity of available standard toxicity data most likely leads to incorrect effect/risk predictions for the compounds detected in the GW plume at our study site. Considering the WFD- 
related requirement for EU member states to evaluate the ecological impact of contaminated sites on surface water bodies, the general lack of ecotoxicity data on the long-term effects of compounds with low toxicity but long environmental persistence (partly facilitated through long-living sources), poses an important problem that should receive increasing scientific and political attention.

The SPEARpesticides index was used to verify minimal expected impact of diffuse source pesticide pollution originating from agricultural and urban sources, and the scores were generally high (28\% $43 \%$, Table 2) indicating minimal impact by diffuse source pesticide pollution at the sampling sites (Liess and von der Ohe 2005; von der Ohe et al. 2007).

\section{Conclusions}

Based on taxon density, diversity measures and NMDS analysis, we showed that macroinvertebrate communities were impaired at the sampling sites S4 and S5 which were additionally characterised by the highest contaminant concentrations in inflowing groundwater. Moreover, we showed that the changes in macroinvertebrate communities were strongest for the fraction of sediment dwelling taxa. Interestingly, none of the currently used macroinvertebrate indices applied in this study, including SPEARorganics, could identify this ecological impairment. This could be due in part to a suboptimal classification of taxonomic sensitivities to organic pollutants in the SPEARorganics index, since e.g. the contaminants characterising the groundwater plume at Grindsted factory site have low toxicity and generally have been tested on a very limited number of supplemental test organisms. Morphological deformities in P. olivacea only occurred at the sites S5 and S6, but the total number of individuals was too low to draw firm conclusions on the mutagenic effects of the groundwater plume. 
463 We conclude that the environmental setting of contaminants with low toxicity to invertebrates 464 continuously discharging into streams from long-lived sources is not sufficiently reflected in the 465 current standard ecotoxicity testing program. A reliable estimate for the physiological sensitivity of 466 organisms to toxicants is essential for any ecological indicator of toxicant effects. However, the 467 production of such toxicity data can become pragmatically, as well as financially challenging. 468 Future studies on ecological effects of contaminated sites could address this problem through i) 469 identifying response patterns in ecological and morphological traits of macroinvertebrates that may 470 be more sensitive than taxonomical endpoints to contaminant pollution (Doledec and Statzner 2008; 471 Statzner and Bêche 2010), and ii) exploring responses in the meio-fauna communities residing in 472 the hyporheic zone where exposure concentrations are higher, and subsequently linking these 473 responses to the benthic macroinvertebrate communities.

476 This work was supported by the Danish Environmental Protection Agency and the Region of 477 Southern Denmark. We thank all people involved in the field studies and laboratory analyses, in 478 particular Jens S. Sørensen, Bent H. Skov, Mikael E. Olsen, Morten Andreasen and Christina M. 479 Hagberg (DTU technicians), and Tommy Silberg and Lise Lauridsen (AU technicians). In addition, 480 we acknowledge Mette F. Petersen's contribution to the field work conducted in 2011. Lastly we 481 thank three anonymous reviewers for their constructive comments that helped improve the 482 manuscript. 
Aisopou A, Bjerg PL, Sonne AT, Balbarini N, Rosenberg L, Binning PJ (2015) Dilution and volatilization of groundwater contaminant discharges in streams. J Contam Hydrol 172: 7183.

Al-Shami S, Rawi CSM, Nor SAM, Ahmad AH, Ali A (2010) Morphological deformities in Chironomus spp. (Diptera: Chironomidae) larvae as a tool for impact assessment of anthropogenic and environmental stresses on three rivers in the Juru river system, Penang, Malaysia. Env Entomol 39:210-222.

Anibas C, Buis K, Verhoeven R, Meire P, Batelaan O (2011) A simple thermal mapping method for seasonal spatial patterns of groundwater-surface water interaction. J Hydrol 397:93-104.

Armitage PD, Moss D, Wright JF, Furse MT (1983) The performance of a new biological water quality score system based on macroinvertebrates over a wide range of unpolluted running water sites. Water Res 17:333-347.

Baun A, Jensen SD, Bjerg PL, Christensen TH, Nyholm N (2000) Toxicity of organic chemical pollution in groundwater downgradient of a landfill (Grindsted, Denmark). Env Sci Technol 34:1647-1652.

Baun A, Kloft L, Bjerg PL, Nyholm N (1999) Toxicity testing of organic chemicals in groundwater polluted with landfill leachate. Env Toxicol Chem 18:2046-2053.

Beketov MA, Liess M (2008) An indicator for effects of organic toxicants on lotic invertebrate communities: Independence of confounding environmental factors over an extensive river continuum. Env Pol 156:980-987.

Beketov MA, Kefford BJ, Schäfer RB, Liess M (2013) Pesticides reduce regional biodiversity of stream invertebrates. Proc Nat Ac Sci USA 110: 11039-11043. 
Brunke M, Gonser T (1999) Hyporheic invertebrates-the clinal nature of interstitial communities structured by hydrological exchange and environmental gradients. J N Am Ben Soc 18:344362.

Baattrup-Pedersen A, Riis T (1999) Macrophyte diversity and composition in relation to substratum characteristics in regulated and unregulated Danish streams. Freshwat Biol 42:375-385.

Chapman SW, Parker BL, Cherry JA, Aravena R, Hunkeler D (2007) Groundwater-surface water interaction and its role on TCE groundwater plume attenuation. J Contam Hydrol 91:203232.

Clarke KR, Warwick RM (2001) Change in marine communities: An approach to statistical analysis and interpretation, 2nd edn. PRIMER-E Ltd., Plymouth Marine Laboratory, UK

Conant B, Cherry JA, Gillham RW (2004) A PCE groundwater plume discharging to a river: influence of the streambed and near-river zone on contaminant distributions. J Contam Hydrol 73:249-279.

Daughton CG (2005) "Emerging" chemicals as pollutants in the environment: a 21st century perspective. Renew Res J 23:6-23.

Di Veroli A, Goretti E, Paumen ML, Kraak MHS, Admiraal W (2012) Induction of mouthpart deformities in chironomid larvae exposed to contaminated sediments. Env Pol 166:212-217.

Dickman M, Rygiel G (1996) Chironomid larval deformity frequencies, mortality, and diversity in heavy-metal contaminated sediments of a Canadian Riverine Wetland. Env Int 22:693-703.

Dickman M, Rygiel G (1998) Municipal landfill impacts on a natural stream located in an urban wetland in regional Niagara, Ontario. Can F-Nat 112:619-630.

Doledec S, Statzner B (2008) Invertebrate traits for the biomonitoring of large European rivers: an assessment of specific types of human impact. Freshwat Biol 53:617-634. 
Edington JM, Hildrew AG (1995) Caseless caddis larvae of the British Isles with notes on their ecology. Freshwater Biological Association, The Ferry House, Far Sawrey, Ambleside, Cumbria LA22 0LP

Ferreiro N, Feijoo C, Giorgi A, Rosso J (2014) Macroinvertebrates select complex macrophytes independently of their body size and fish predation risk in a Pampean stream. Hydrobiol 740:191-205.

Friberg N, Skriver J, Larsen SE, Pedersen ML, Buffagni A (2010) Stream macroninvertebrate occurrence along gradients in organic pollution and eutrophication. Freshwat Biol 55:14051419.

Gagliardi B, Pettigrove V (2013) Removal of intensive agriculture from the landscape improves aquatic ecosystem health. Agric Ecosyst Env 176:1-8.

Gotelli NJ, Colwell RK (2001) Quantifying bidiversity: Procedures and pitfalls in the measurement and comparison of species richness. Ecol Lett 4: 379-391.

Heron G, Bjerg PL, Gravesen P, Ludvigsen L, Christensen TH (1998) Geology and sediment geochemistry of a landfill leachate contaminated aquifer (Grindsted, Denmark). J Contam Hydrol 29:301-317.

Höss S, Claus E, Von der Ohe PC, et al. (2011) Nematode species at risk - A metric to assess pollution in soft sediments of freshwaters. Env Int 37:940-949.

Houde M, Douville M, Gagnon P, Sproull J, Cloutier F (2015) Exposure of Daphnia magna to trichloroethylene (TCE) and vinyl chloride (VC): Evaluation of gene transcription, cellular activity, and life-history parameters. Ecotoxicol Env Saf 116: 10-18.

Jensen F (1984) A revision of the taxonomy and distribution of the Danish black-flies (Diptera: Simuliidae), with keys to the larval and pupal stages. Natura Jutlandica 21:69-116. 
Kovalenko KE, Thomaz SM, Warfe DM (2012) Habitat complexity: approaches and future directions. Hydrobiol 685:1-17.

Lenat DR (1983) Chironomid taxa richness: Natural variation and use in pollution assessment. Freshwat Inv Biol 2:192-198.

Lenat DR (1993) Using mentum deformities of Chironomus larvae to evaluate the effects of toxicity and organic loading in streams. J N Am Bent Soc 12:265-269.

Lenat DR, Penrose DL, Eagleson KW (1981) Variable effects of sediment addition on stream benthos. Hydrobiol 79:187-194.

Liess M, von der Ohe PC (2005) Analyzing effects of pesticides on invertebrate communities in streams. Env Toxicol Chem 24:954-965.

McKnight US, Funder SG, Rasmussen JJ, Finkel M, Binning PJ, Bjerg PL (2010) An integrated model for assessing the risk of TCE groundwater contamination to human receptors and surface water ecosystems. Ecol Eng 36:1126-1137.

McKnight US, Rasmussen JJ, Kronvang B, Binning PJ, Bjerg PL (2015) Sources, occurrence and predicted aquatic impact of legacy and contemporary pesticides in streams. Env Pol 200:6476.

McKnight US, Rasmussen JJ, Kronvang B, Bjerg PL, Binning PJ (2012) Integrated assessment of the impact of chemical stressors on surface water ecosystems. Sci Tot Env 427-428:319331.

Meregalli G, Pluymers L, Ollevier F (2001) Induction of mouthpart deformities in Chironomus riparius larvae exposed to 4-n-nonylphenol. Env Pol 111:241-246.

Milosevic D, Simic V, Stojkovic M, et al. (2013) Spatio-temporal pattern of the Chironomidae community: toward the use of non-biting midges in bioassessment programs. Aquat Ecol $47: 37-55$. 
Milosevic N, Thomsen NI, Juhler RK, Alberechtsen H-J, Bjerg PL (2012) Identification of discharge zones and quantification of contaminant mass discharges into a local stream from a landfill in a heterogeneous geologic setting. J Hydrol 446:13-23.

Moller Pillot HKM (2009) Chironomidae larvae: Bilogy and ecology of the Chironomini. KNNV Publishing, Koninklijke Wöhrmann BV, The Neterlands.

Nielsen SS, Tuxen N, Frimodt O, et al. (2014) Risk assessment of surface water impacted by point source related contaminated groundwater (In Danish). Danish EPA, Copenhagen, Denmark, $176 \mathrm{pp}$.

Nilsson A (2005) Aquatic insects of Northern Europe: A taxonomic handbook. Apollo Books.

NIRAS (2009) A historical overview of the contamination in Grindsted (In Danish). Technical Report No 04/350. Ribe County.

Petersen MF (2012) Quantification and risk assessment of continuous micropollutant mass dischargees from multiple sources to a gaining stream at the catchment scale. Master Thesis, Technical University of Denmark.

Plotkin S, Ram NM (1984) Multiple bioassays to assess the toxicity of a sanitary landfill site. Arch Env Cont Toxicol 13:197-206.

Rasmussen JJ, Baattrup-Pedersen A, Larsen SE, Kronvang B (2011) Local physical habitat quality cloud the effect of predicted pesticide runoff from agricultural land in Danish streams. J Env Monit 13:943-950.

Rasmussen JJ, McKnight US, Loinaz MC, et al. (2013) A catchment scale evaluation of multiple stressor effects in headwater streams. Sci Tot Env 442:420-431.

Rosenberg DM, Resh VH (1993) Freshwater biomonitoring and benthic macroinvertebrates Chapman \& Hall, London. 
Roy JW, Bickerton G (2012) Toxic Groundwater Contaminants: An Overlooked Contributor to Urban Stream Syndrome? Env Sci Technol 46:729-736.

Rubach MN, Baird DJ, Van den Brink PJ (2010) A new method for ranking mode-specific sensitivity of freshwater arthorpods to insecticides and its relationship to biological traits. Env Toxicol Chem 29:476-487.

Schäfer RB, von der Ohe PC, Rasmussen JJ, Kefford B, Beketov M, Schulz R, Liess M (2012) Thresholds for the effects of pesticides on invertebrate communities and leaf breakdown in streams. Env Sci Technol 46: 5134-5142.

Servia MJ, Cobo F, Gonzalez MA (1998) Deformities in larval Prodiamesa olivacea (Meigen, 1818) (Diptera, Chironomidae) and their use as bioindicators of toxic sediment stress. Hydrobiol 385:153-162.

Skriver J, Friberg N, Kirkegaard J (2000) Biological assessment of running waters in Denmark: introdution of the Danish Stream Fauna Index (DSFI). Verh Int V Limnol 27:1822-1830.

Statzner B, Bêche LA (2010) Can biological traits resolve effects of multiple stressors on running water ecosystems? Freshwat Biol 55:80-119.

Tesoriero AJ, Duff JH, Saad DA, Spahr NE, Wolock DM (2013) Vulnerability of Streams to Legacy Nitrate Sources. Env Sci Technol 47(8):3623-3629

Vallenduuk HJ, Moller Pillot HKM (2007) Chironomidae larvae: General ecology and Tanypodinae. KNNV Publishing, De Budelse bv, Budel, The Netherlands.

von der Ohe PC, Liess M (2004) Relative sensitivity distribution of aquatic invertebrates to organic and metal compounds. Env Toxicol Chem 23:150-156

von der Ohe PC, Prub A, Schafer RB, Liess M, de Deckere E, Brack W (2007) Water quality indices across Europe - a comparison of the good ecological status of five river basins. J Env Monit 9:970-978. 
Wallace ID, Wallace B, Phillipson GN (2003) Keys to the case-bearing caddis larvae of Britain and Ireland. Freshwater Biological Association.

Watts MM, Pascoe D, Carroll K (2001) Chronic exposure to 17 alpha-ethinylestradiol and bisphenol A-effects on development and reproduction in the freshwater invertebrate Chironomus riparius (Diptera : Chironomidae). Aquat Toxicol 55:113-124.

Watts MM, Pascoe D, Carroll K (2003) Exposure to 17 alpha-ethinylestradiol and bisphenol Aeffects on larval moulting and mouthpart structure of Chironomus riparius. Ecotoxicol Env Saf 54:207-215.

Weatherill J, Krause S, Voyce K, Drijfhout F, Levy A, Cassidy N (2014) Nested monitoring approaches to delineate groundwater trichloroethene discharge to a UK lowland stream at multiple spatial scales. J Contam Hydrol 158:38-54.

Westbrook SJ, Rayner JL, Davis GB, Clement TP, Bjerg PL, Fisher ST (2005) Interaction between shallow groundwater, saline surface water and contaminant discharge at a seasonally and tidally forced estuarine boundary. J Hydrol 302:255-269.

Whatley MH, van Loon EE, van Dam H, Vonk JA, van der Geest HG, Admiraal W (2014) Macrophyte loss drives decadal change in benthic invertebrates in peatland drainage ditches. Freshwat Biol 59:114-126.

Wiederholm T (1983) Chironomidae of the Holarctic region, vol 19. Entomologica Scandinavica, Borgströms Tryckeri AB, Motala, Sweden.

Winslow SD, Martin JJ, Hallberg GR, et al. (2006) Statistical procedures for the determination and verification of minimum reporting levels for drinking water methods. Env Sci Technol 40:281-288. 
647 Table 1. Concentrations of selected chemicals in stream water (SW) and water extracted from the hyporheic zone (HZ). Where appropriate,

648 ranges of values are given, representing water samples collected at the seven sampling sites in Grindsted stream ( $\pm 50 \mathrm{~m})$ in $2011($ Table

649 S2) and 2012 (Table S3). NA stands for no available data.

\begin{tabular}{|c|c|c|c|c|c|c|c|c|c|c|}
\hline \multirow[t]{2}{*}{$\begin{array}{l}\text { Macroinvertebrate sampling site } \\
\text { (distance from S7 (m)) }\end{array}$} & \multirow{2}{*}{$\begin{array}{l}\text { S1 }(15,844) \\
\text { SW }\end{array}$} & \multirow{2}{*}{$\begin{array}{l}\mathrm{S} 2(13,344) \\
\mathrm{SW}(\mathrm{n}=2)\end{array}$} & \multicolumn{2}{|c|}{ S3 $(10,894)$} & \multicolumn{2}{|l|}{ S4 $(7,952)$} & \multicolumn{2}{|l|}{ S5 $(7,594)$} & \multirow{2}{*}{$\begin{array}{l}\text { S6 }(7,171) \\
\text { SW }\end{array}$} & \multirow{2}{*}{$\begin{array}{l}\text { S7 } \\
\text { SW }\end{array}$} \\
\hline & & & SW $(n=2)$ & $\mathrm{HZ}$ & SW $(n=2)$ & $\mathrm{HZ}(\mathrm{n}=2)$ & $\mathrm{SW}(\mathrm{n}=2)$ & $\mathrm{HZ}$ & & \\
\hline \multicolumn{11}{|l|}{ Chlorinated solvents } \\
\hline $\operatorname{PCE}\left(\mu \mathrm{g} \mathrm{L}^{-1}\right)$ & $<0.04$ & $0.07-0.09$ & $0.08-0.13$ & 0.35 & $0.13-0.18$ & $0.1 *$ & 0.08 & 0.05 & $<0.04$ & $<0.04$ \\
\hline TCE $\left(\mu \mathrm{g} \mathrm{L}^{-1}\right)$ & $<0.04$ & 0.050 .06 & 0.05-0.09 & 0.26 & $0.11-0.16$ & $0.15-0.40$ & $0.05-0.06$ & 0.04 & $<0.04$ & $<0.04$ \\
\hline cis-DCE $\left(\mu \mathrm{g} \mathrm{L}^{-1}\right)$ & 0.14 & $1.20-1.41$ & $1.50-2.07$ & 2.54 & $2.89-5.01$ & $4.40-9.30$ & $0.29-0.33$ & 0.23 & $<0.05$ & $<0.05$ \\
\hline Vinyl chloride $\left(\mu \mathrm{g} \mathrm{L}^{-1}\right)$ & 0.11 & $0.44-1.09$ & $0.54-2.13$ & 0.23 & $3.22-4.59$ & $43-252$ & $0.34-0.36$ & 0.21 & $<0.05$ & $<0.05$ \\
\hline \multicolumn{11}{|l|}{ Pharmaceutical compounds } \\
\hline Sulfaguanidine $\left(\mu \mathrm{g} \mathrm{L}^{-1}\right)$ & NA & $0.58-0.80$ & $0.84 * *$ & NA & NA & $18 * *$ & NA & NA & $<0.5$ & $<0.5$ \\
\hline Sulfamethazine $\left(\mu \mathrm{g} \mathrm{L}^{-1}\right)$ & NA & $0.97-1.1$ & $1.3 * *$ & NA & NA & $<0.5^{* *}$ & NA & NA & $<0.5$ & $<0.5$ \\
\hline Sulfamethiazole $\left(\mu \mathrm{g} \mathrm{L}^{-1}\right)$ & NA & $0.60-1.20$ & $1.4 * *$ & NA & NA & $<0.05 * *$ & NA & NA & $<0.05$ & $<0.05$ \\
\hline Sulfadiazin $\left(\mu \mathrm{g} \mathrm{L}^{-1}\right)$ & NA & $0.03-0.08$ & $0.025 * *$ & NA & NA & $<0.05 * *$ & NA & NA & $<0.05$ & $<0.05$ \\
\hline Sulfanilic acid $\left(\mu \mathrm{g} \mathrm{L}^{-1}\right)$ & NA & $1.90 *$ & $2.4^{* *}$ & NA & NA & $1.0 * *$ & NA & NA & $<0.5$ & $<0.5$ \\
\hline Barbital $\left(\mu \mathrm{g} \mathrm{L}^{-1}\right)$ & NA & $<1.0$ & 1.2 & NA & NA & $6.8 * *$ & NA & NA & NA & NA \\
\hline Isopropylbarbituric acid $\left(\mu \mathrm{g} \mathrm{L}^{-1}\right)$ & NA & $<1.0$ & $<1.0$ & NA & NA & $9.5^{* *}$ & NA & NA & NA & NA \\
\hline
\end{tabular}

$650 *$ Concentration of the compound $>$ LOQ for only one of the replicate samples

$651 * *$ Concentrations of the pharmaceutical compounds are based on one sample 
Table 2. Macroinvertebrate metrics and diversity measures for the seven sampling sites

\begin{tabular}{|c|c|c|c|c|c|c|c|}
\hline & $\mathrm{S} 1$ & $\mathrm{~S} 2$ & S3 & S4 & S5 & S6 & S7 \\
\hline \multicolumn{8}{|l|}{ All taxonomic groups } \\
\hline Taxonomic density & 25 & 27 & 23 & 13 & 17 & 25 & 31 \\
\hline Abundance (ind. $\mathrm{m}^{-2}$ ) & 605 & 1022 & 1577 & 5473 & 2175 & 3745 & 4220 \\
\hline Simpson index & 0.75 & 0.71 & 0.75 & 0.50 & 0.75 & 0.62 & 0.66 \\
\hline Shannon index & 1.79 & 1.73 & 1.77 & 1.05 & 1.67 & 1.18 & 1.79 \\
\hline Brillouin index & 1.70 & 1.66 & 1.73 & 1.04 & 1.20 & 1.37 & 1.57 \\
\hline \# EPT taxa & 7 & 6 & 8 & 4 & 8 & 11 & 11 \\
\hline EPT abundance & 16 & 32 & 205 & 133 & 108 & 528 & 193 \\
\hline ASPT & 5.27 & 5.13 & 5.46 & 6.00 & 6.08 & 5.86 & 5.31 \\
\hline DSFI score & 5 & 5 & 5 & 5 & 5 & 5 & 5 \\
\hline Pos. div. groups (DSFI) & 7 & 5 & 6 & 4 & 8 & 8 & 10 \\
\hline Neg. div. groups (DSFI) & 1 & 1 & 2 & 0 & 0 & 1 & 4 \\
\hline SPEARorganics & -0.37 & -0.34 & -0.19 & -0.19 & -0.23 & -0.18 & -0.35 \\
\hline SPEARpesticides & 40.23 & 34.94 & 43.09 & 42.17 & 41.92 & 45.47 & 28.84 \\
\hline \multicolumn{8}{|l|}{ Sediment taxa } \\
\hline Taxonomic density & 8 & 7 & 6 & 3 & 2 & 5 & 6 \\
\hline Abundance (ind. $\mathrm{m}^{-2}$ ) & 32 & 40 & 35 & 12 & 8 & 22 & 227 \\
\hline Simpson index & 0.73 & 0.67 & 0.70 & 0.61 & 0.32 & 0.75 & 0.60 \\
\hline Shannon index & 1.69 & 1.43 & 1.46 & 1.00 & 0.50 & 1.46 & 1.12 \\
\hline Brillouin's index & 1.29 & 1.21 & 1.17 & 0.71 & 0.32 & 1.11 & 1.06 \\
\hline SPEARorganics & -0.55 & -0.41 & -0.45 & -0.37 & -0.36 & -0.38 & -0.39 \\
\hline \multicolumn{8}{|l|}{ Chironomidae } \\
\hline Taxonomic density & 6 & 7 & 6 & 4 & 1 & 5 & 8 \\
\hline Abundance (ind. $\mathrm{m}^{-2}$ ) & 28 & 40 & 35 & 20 & 2 & 23 & 72 \\
\hline Simpson index & 0.67 & 0.71 & 0.70 & 0.58 & 0 & 0.73 & 0.66 \\
\hline Shannon index & 1.43 & 1.51 & 1.46 & 1.08 & 0 & 1.43 & 1.36 \\
\hline Brillouin's index & 1.10 & 1.22 & 1.17 & 0.81 & 0 & 1.10 & 1.16 \\
\hline $\begin{array}{l}\text { P. olivacea } \text { deformities } \\
\text { (\#deformities/total \# ind) }\end{array}$ & $0 / 9$ & $0 / 5$ & $0 / 0$ & $0 / 1$ & $1 / 1$ & $2 / 4$ & $0 / 1$ \\
\hline
\end{tabular}

653

654

655 
657 value is given \pm Std. dev. $(n=10)$. Discharge was measured at stations $S 1$, S5 and S7 $(n=4)$.

\begin{tabular}{llllllll}
\hline Parameter & S1 & S2 & S3 & S4 & S5 & S6 & S7 \\
\hline Wetted width (m) & $7.9 \pm 0.8$ & $8.9 \pm 0.9$ & $10.2 \pm 1.0$ & $10.3 \pm 1.5$ & $10.1 \pm 1.2$ & $10.3 \pm 1.5$ & $15.5 \pm 2.4$ \\
$\%$ boulder & 0 & 0 & 0 & $3 \pm 5$ & 0 & 0 & $1 \pm 2$ \\
$\%$ gravel & $16 \pm 11$ & $11 \pm 15$ & 0 & $13 \pm 9$ & $11 \pm 9$ & $5 \pm 5$ & $21 \pm 16$ \\
$\%$ sand & $82 \pm 10$ & $81 \pm 16$ & $94 \pm 5$ & $83 \pm 12$ & $85 \pm 7$ & $88 \pm 8$ & $34 \pm 12$ \\
$\%$ mud & $2 \pm 5$ & $8 \pm 10$ & $6 \pm 6$ & $1 \pm 3$ & $4 \pm 3$ & $7 \pm 9$ & $44 \pm 17$ \\
$\%$ roots & 0 & $20 \pm 9$ & 0 & 0 & $1 \pm 1$ & 0 & 0 \\
\% submerged vegetation & $29 \pm 10$ & $50 \pm 11$ & $46 \pm 14$ & $72 \pm 23$ & $72 \pm 20$ & $65 \pm 19$ & $36 \pm 9$ \\
\% emerged vegetation & $27 \pm 5$ & $21 \pm 11$ & $27 \pm 11$ & $13 \pm 5$ & $12 \pm 5$ & $20 \pm 10$ & $54 \pm 10$ \\
$\%$ undercut banks & 0 & $39 \pm 12$ & 0 & $3 \pm 5$ & $3 \pm 5$ & $3 \pm 5$ & $5 \pm 11$ \\
\% high energy flow & $9 \pm 9$ & $10 \pm 6$ & $8 \pm 5$ & $14 \pm 14$ & $13 \pm 14$ & $14 \pm 14$ & $7 \pm 5$ \\
Discharge $\left(\mathrm{L} \mathrm{s}^{-1}\right)$ & $2249 \pm 16$ & NA & NA & NA & $1892 \pm 19$ & NA & $1152 \pm 2$ \\
\hline
\end{tabular}

658

659 Table 4. Chemical and physicochemical properties of the seven sampling sites (S1-S7) in Grindsted

660 stream.

\begin{tabular}{|c|c|c|c|c|c|c|c|}
\hline Parameter & S1 & S2 & S3 & S4 & S5 & S6 & S7 \\
\hline \multicolumn{8}{|l|}{ Water chemistry } \\
\hline Ammonia-N $\left(\mathrm{mg} \mathrm{L}^{-1}\right)$ & 0.043 & 0.076 & 0.099 & 0.098 & 0.096 & 0.099 & 0.114 \\
\hline Nitrate-N $\left(\mathrm{mg} \mathrm{L}^{-1}\right)$ & 3.14 & 2.95 & 2.91 & 3.28 & 3.26 & 3.28 & 3.08 \\
\hline Total N $\left(\mathrm{mg} \mathrm{L}^{-1}\right)$ & 3.16 & 2.99 & 3.1 & 3.4 & 3.38 & 3.55 & 3.21 \\
\hline ortho-phosphate $\left(\mathrm{mg} \mathrm{L}^{-1}\right)$ & 0.018 & 0.03 & 0.011 & 0.013 & 0.013 & 0.012 & 0.012 \\
\hline Total $\mathrm{P}\left(\mathrm{mg} \mathrm{L}^{-1}\right)$ & 0.102 & 0.116 & 0.078 & 0.075 & 0.073 & 0.08 & 0.079 \\
\hline $\mathrm{BOD}_{5}\left(\mathrm{mg} \mathrm{O}_{2} \mathrm{~L}^{-1}\right)$ & 1.28 & 1.37 & 1.44 & 1.44 & 1.34 & 1.4 & 1.9 \\
\hline Susp. particles $\left(\mathrm{mg} \mathrm{L}^{-1}\right)$ & 2.7 & 2.9 & 2.4 & 2.7 & 3.6 & 2.5 & 1.9 \\
\hline Susp. organic particles $\left(\mathrm{mg} \mathrm{L}^{-1}\right)$ & 1.3 & 1.5 & 1.3 & 1.5 & 1.6 & 1.3 & 1.1 \\
\hline \multicolumn{8}{|l|}{ Physicochemical properties } \\
\hline $\mathrm{pH}$ & 6.52 & 6.68 & 6.52 & 6.56 & 6.5 & 6.52 & 6.75 \\
\hline Temperature $\left({ }^{\circ} \mathrm{C}\right)$ & 13.4 & 13.5 & 13.4 & 13.1 & 13.2 & 12.9 & 12.8 \\
\hline Conductivity $\left(\mu \mathrm{S} \mathrm{cm}^{-1}\right)$ & 274 & 286 & 264 & 272 & 273 & 272 & 237 \\
\hline
\end{tabular}


Figure captions:

663

664 Fig. 1. Schematic overview of the seven sampling sites in Grindsted stream and the contaminated 665 factory site.

666

667 Fig. 2. NMDS plot including all taxonomic groups detected in the fauna samples for the seven 668 sampling sites. The level of stress was 0.01 .

669

670 Fig. 3. NMDS plot including sediment dwelling taxa detected in the fauna samples for the seven 671 sampling sites. The level of stress was $<0.01$.

672 